\title{
list of new members
}

The Council has approved the election of the following candidates to the grade of Member:

\section{$342 n d$ List of Candidates for Member}

Allen, William L. Anderson, Paul $\mathrm{H}$. Bannon, Peter R. Bass, Arthur Bono, Michael S. Bradley, James H. S.

Haendel, Theodore F. Hantel, Michael Hemphill, Tony L. Hinton, Barry B. Howes, Ronald L. Jakobbson, Thor E.

Peake, Jeffrey S. Pope, Frederick B., III Madala, Rangarao Rao, K. Shankar Riley, James J.

Abeele, Willy V. Aoki, Tadao Baradas, Maximo W. Baskett, Ronald L. Bedard, James C. Behrend, William O.

Eskinazi, Salamon N. Gaertner, John P. Ghovanlou, Ali H. Gilpatrick, Marvin C. Haase, Dennis L. Hamill, Patrick J.

Burbridge, Fred E.

Calheiros, Roberto V.

Chimento, Charles J.

Chimonas, George

Cross, Ralph D.

D'Errico, Robert E.

343rd List of Candidates for Member

Jenssen, Ditmar

Johnson, Andrew, Jr.

Johnson, Richard G.

Kelly, Edward H.

Kistler, Robert E.

Koplowitz, Ralph M.
Dewey, Kenneth F.

Dierking, Carl F.

Drag, Walter $\mathrm{H}$.

Durham, Richard

El-Sayed, Hassan

Ely, Curtis D.
Erickson, Edward N. Fauquet, Ronald L. Fisher, Richard W. Gerber, Hermann E. Grebe, Robert D. Hack, Walter A.

\section{4th List of Candidates for Member}

Sanders, John K.

Sagert, Peter G.

Schieldge, John P.

Severance, Robert W.

Shea, Dennis J.
Koziara, Michael C. Landry, Claude R. Little, C. Gordon Maarouf, Abdel R. McFarlane, Norman A. McNaughton, Daniel J.
Mosher, Frederick R. Moskowitz, Harvey $\mathbf{L}$. Nolan, Daniel A. O'Brien, Gerald F. Overland, James E. Peach, Lester C.

Vietti, Michael A. Zwack, Peter $P$.

\section{5th List of Candidates for Member}

Benincasa, Mario

Berman, Elizabeth A.

Bjerkaas, Carlton L.

Blackmon, Maurice L.

Bloudek, William J., Jr.

Bowen, Russell L., Jr.
Skiles, Newton K. Strope, Marvin B. Sweet, Wayne A.

Tomlinson, Michael A.

Trischka, John W.

\section{6th List of Candidates for Member}

Hayes, Charles K. Henning, William $\mathrm{H}$. Hess, H. Allen Hickey, Richard D. Horn, Robert J., III Huyer, Adriana
Bradley, Raymond S. Campbell, Gaylon S. Capirci, Ricci

Chen, Jye Cooper, William A. Crowson, Delmar L.
Davis, Charles I. Drag, Walter $\mathrm{H}$. Dunsmore, Howard L. Eaton, Larry R. Emmanuel, Constantinos B. Ermel, Michael R.
Knable, Carl R. Knox, Robert A. Kuo, Han-Hsiung Leduc, Richard $\mathbf{R}$. Lewis, John E., Jr. Lewis, Norman F. 
347th List of Candidates for Member

Lewis, Roy R.

Lubard, Stephen C.

Maher, William J.

Mann, David M.

Mannie, Rollin E.

McCallum, John A.
Meisel, William S.

Miller, Jim L.

Monk, John D.

Mumford, Warren G.

Nurnberger, Fred V.

Paillet, Frederick L.
Parsons, Kenneth E.

Parton, William J., Jr.

Peckenpaugh, James A.

Pellegrini, John J.

Phillips, Edwin A.

Pinkerton, John E.
Pratt, Jeremiah T. O.

Rai, Dharmbir

Regas, James L.

Rosenstein, Marvin

Samson, Perry J.

Sandberg, David V.

\section{8th List of Candidates for Member}

Scattarella, Kim D. Schulz, Kenneth A. Scuka, Viktor Serafin, Robert J. Smith, David R. Smith, Michael R.
Smith, Peter C.

Stone, Richard J.

Sullivan, David A.

Summer, Solomon G.

Taylor, Richard S.

Tobriner, Matthew W.
Trask, David C.

Venkatesh, Srinivasan

Vinzani, Peter G.

Walterscheid, Richard L.

Wantz, James F.

Wastrack, Kenneth G.
Weare, Bryan C.

Weil, Jeffrey $C$.

Wendell, Larry L.

White, John L.

Wolfson, Noah

Zajdel, Thomas D.

\section{(Continued from announcements, page 83)}

Microclimate: the biological environment (Norman J. Rosenberg, 1974, 315 pp., $\$ 13.50$ hardbound, from Wiley-Interscience, a division of John Wiley \& Sons, Inc., 605 Third Ave., New York, N.Y. 10016) provides a physical description of microclimate, or "climate near the ground," with sections on radiation balance; soil heat flux and soil temperature; sensible heat flux, surface and air temperature; wind and turbulent transport; atmospheric humidity; modification of the solar temperature regime; windbreaks and the shelter effect; frost and frost control; and improving water use efficiency.

The following NOAA Technical Reports are now available:

Development of a portable acoustic echo sounder (NOAA-TRERL-298-WPL-31, Edward J. Owens, 1974, 48 pp., 45 cents paper copy from Superintendent of Documents, U.S. Government Printing Office, Washington, D.C. 20402, $\$ 2.25$ microfiche as NOAA-74071710 from National Technical Information Service, 5285 Port Royal Rd., Springfield, Va. 22151.

Environmental Research Laboratories radiation programs requirements and recommendations (NOAA-TR-ERL-300-OD12, Kirby Hanson, Edwin Flowers, Gary Herbert, Douglas Hoyt, and Peter Kuhn, 1974, 26 pp., 65 cents paper copy from GPO, above, $\$ 2.25$ microfiche as NOAA-74071712 from NTIS, above).

The Nimbus 5 data catalog, volumes 5 and 6 (prepared by Allied Research Associates, Inc., Baltimore, Md., for the ERTS/Nimbus Project, March and April 1974, n.p. paperbound, from the Goddard Space Flight Center, Greenbelt, Md. 20770) contains data from 1 August 1973 through 30 September 1973 (Vol. 5) and from 1 October 1973 through 30 November 1973 (Vol. 6).

Programs and accomplishments, National Weather Service Systems Development Office, fiscal year 1974 (NOAA-74111802, 1974, 62 pages, n.p. paperbound, available from NTIS in March 1975, above) summarizes significant accomplishments in the applied research and development programs of the NWS Systems Development Office. Programs include: Auto- mation of Field Operations and Services (AFOS); AFOS Digitized Radar Experiment; AFOS Forecast Applications; Remote Automatic Meteorological Observing Stations (RAMOS); Next generation Upper Air System (NEXAIR); Public Weather Prediction, Severe Local Storms; Marine Environmental Prediction; and Terminal Weather Prediction.

Radiological and environmental research division, Argonne National Laboratory, annual report: atmospheric physics, January-December 1973 (ANL-8060, Part IV, R. E. Rowland, Division Director, P. Frenzen, Section Head, 1974, 98 pp., $\$ 5.45$ paper copy, $\$ 1.45$ microfiche, from NTIS, above) contains papers on various aspects of programs of Argonne's Atmospheric Physics Division, with increased emphasis on atmospheric boundary-layer investigations.

Readings on the climate of West Malaysia and Singapore (Oxford in Asia University Readings, Ooi Jin Bee and Chia Lin Sien, 1974, 262 pp., $\$ 26.00$ hardbound, from Oxford University Press, 200 Madison Ave., New York, N.Y. 10016) discusses upper air climatology, climatic elements, and applied climatology in a primary producing country, West Malaysia, and on the rapidly industrializing Singapore Island.

Systems approach to air pollution control (Robert J. Bibbero and Irving G. Young, 1974, 531 pp. $\$ 24.95$ hardbound, from Wiley-Interscience, see above) contains chapters on air pollutants: sources, sinks, and residence times; economic costs of air pollution; legislative basis of air pollution control systems; control strategies and systems design; data acquisition and monitoring; applications of air pollution data; mathematical models of air pollution; community air quality management; gas and vapor-monitoring instruments; particulate-monitoring instruments; and the future of air pollution control systems.

The use of weather and climatological data in evaluating the durability of building components and materials (TN-838, National Bureau of Standards, Larry W. Masters and Winthrop C. Wolfe, 1974, 101 pp., paper copy $\$ 1.45$ as C13.46:838 from GPO, see above, foreign remittances must include $25 \%$ of publication price for mailing costs; microfiche $\$ 1.45$ domestic, $\$ 2.95$ foreign, as COM-74-50841 from NTIS, above).

(More announcements on page 97) 